\title{
A Battery of Soil and Plant Indicators of NBS Environmental Performance in the Context of Global Change
}

\author{
Pilar Andrés ${ }^{1, *}$, Enrique Doblas-Miranda ${ }^{1,2}{ }^{\oplus}$, Stefania Mattana ${ }^{3}{ }^{(}$, Roberto Molowny-Horas ${ }^{1}$, Jordi Vayreda ${ }^{1}{ }^{(\mathbb{C}}$, \\ Moisès Guardiola ${ }^{4}\left(\mathbb{D}\right.$, Joan Pino ${ }^{1,2} \mathbb{\oplus}$ and Javier Gordillo ${ }^{1}$ \\ 1 CREAF, Campus UAB, Edifici C, 08193 Bellaterra, Barcelona, Spain; e.doblas@creaf.uab.cat (E.D.-M.); \\ roberto@creaf.uab.cat (R.M.-H.); j.vayreda@creaf.uab.cat (J.V.); joan.pino@uab.cat (J.P.); \\ j.gordillo@creaf.uab.cat (J.G.) \\ 2 Universitat Autònoma de Barcelona, 08193 Bellaterra, Barcelona, Spain \\ 3 Research Group Plants and Ecosystems (PLECO), Department of Biology, University of Antwerp, \\ B-2610 Wilrijk, Belgium; Stefania.Mattana@uantwerpen.be \\ 4 Unitat de Botànica, Departament de Biologia Animal, de Biologia Vegetal i d'Ecologia, \\ Universitat Autònoma de Barcelona, 08193 Bellaterra, Barcelona, Spain; moises.guardiola@uab.cat \\ * Correspondence: pilar.andres@creaf.uab.cat; Tel.: +34-935814680
}

Citation: Andrés, P.;

Doblas-Miranda, E.; Mattana, S.;

Molowny-Horas, R.; Vayreda, J.;

Guardiola, M.; Pino, J.; Gordillo, J. A Battery of Soil and Plant Indicators of NBS Environmental Performance in the Context of Global Change.

Sustainability 2021, 13, 1913.

https://doi.org/10.3390/su13041913

Academic Editor: Gerd Lupp

Received: 16 December 2020

Accepted: 4 February 2021

Published: 10 February 2021

Publisher's Note: MDPI stays neutral with regard to jurisdictional claims in published maps and institutional affiliations.

Copyright: (C) 2021 by the authors Licensee MDPI, Basel, Switzerland. This article is an open access article distributed under the terms and conditions of the Creative Commons Attribution (CC BY) license (https:/ / creativecommons.org/licenses/by/ $4.0 /)$.

\begin{abstract}
Nature-based solutions (NBSs) for risk reduction produce environmental effects that must be assessed to evaluate their performance. In a context of climate change and growing concern about the loss of biodiversity, indicators informing about ecosystem complexity, resilience and stability are required. NBS projects hardly ever include environmental monitoring programs and, at best, NBS performance is evaluated based on elementary indicators that provide poor information about ecosystem functions and services. Within the framework of the PHUSICOS (EU, H2020) project, a NBS approach is being applied to reduce the hydrometeorological risks (rock falls and snow avalanches) that threaten a transnational road and a very populated town in the Pyrenees range. In both cases, the planned actions are modifying soil and vegetation structure and functioning as well as the environmental services they provide. Here we present a set of soil and plant indicators designed to be included in the postoperation monitoring plan of both NBS projects. We provide a description and information about the range of values of every indicator measured in the study sites together with indications about analytical methods and sampling calendar. We discuss the trade-offs between monetary cost, expertise requirements and meaningfulness of the indicators.
\end{abstract}

Keywords: NBS monitoring; hydrogeological risks; environmental services; soil bioindicators; plant indicators; rock falls; snow avalanches

\section{Introduction}

The IPCC report on the management of the risks of extreme events and disasters [1] warned about increasing frequency of extreme climate events (such as heavy rainfalls, drought and heat waves) over many areas of the globe during the 21st century. The consequences of this upsurge for Europe in the form of glacier retreat, increase in landslides and rock slope failures and changed occurrence of extreme river discharges and floods were documented two years later [2].

Landslides, including the fall of rocks from vertical surfaces and rock and sediment topples and avalanches are important threats for soil conservation in mountainous and hilly areas across Europe [3]. Besides the natural instability of the land due to steep slopes and susceptible lithology [4], full water saturation after long lasting heavy rainfall and improper land cover (i.e., deforestation after forest fire) or land management (i.e., steep road cuts, changes in hydrology) are key factors in landslide occurrence. In the 2015-2017 period, landslides caused 39 deaths and 155 injuries in Europe, and 48 million people are currently exposed to landslide hazard [5]. In high mountain areas, changes in snow 
pattern and glacier melting are altering the quantity and quality of water and the seasonal hydrological regime of the rivers, particularly where melting water accounts for a large fraction of the streamflow [6]. In some regions, snow avalanches caused by unstable wet snow have increased, and glacier retreat and permafrost thaw are lessening the stability of mountain slopes. Snow cover, glaciers and permafrost will continue to decline throughout the 21st century while increasing number of people and infrastructures are exposed to the subsequent hazards because of growing population, tourism and socioeconomic development [7].

For many years, landslide and rock fall prevention has been based on hard engineering solutions under four main approaches: (I) regrading the slope, (II) draining it to reduce the pore pressures and (III) reinforcing the slope internally or externally with retaining and anchor walls or (IV) with different types of surface textiles in the less severe cases $[8,9]$. Engineered snowpack supporting structures (rigid or nets) are classical methods to anchor the snow cover, to impede fracture propagation in the snow, and to stop small avalanches before they gain momentum and volume. Although being very expensive to build and maintain, these measures are used extensively when protecting inhabited or highly frequented zones [10].

Recently, as an alternative to these engineered or so-called "grey" solutions, a new set of "nature-based solutions" (NBSs) that exploit natural elements and processes have been proposed for risk reduction. The NBS concept was openly launched to the public in the 2012 IUCN World Conservation Congress (Jeju, Republic of Korea) as an overarching framework to face climate change, to guarantee food and nutrition security and to foster economic and social development [11]. In 2013, the European Commission (EC) began to stimulate city greening by NBSs [12] and, in 2015, the Sendai Framework for Disaster Risk Reduction acknowledged NBSs as promising tools in reducing the risk of hydrogeological disasters [13]. NBSs are "solutions that are inspired and supported by nature, which are cost-effective, simultaneously provide environmental, social and economic benefits and help build resilience" [14]. From an integrative perspective, NBSs are intended to be efficient in risk reduction while producing collateral benefits in the societal and environmental fields. NBSs are required to provide environmental cobenefits in the field of climate change mitigation as well as to cooperate in biodiversity conservation and recovery [12]. Together with innovative approaches in the social arena (particularly concerning democratization in decision-making, although this part is beyond the scope of the present study), the NBS strategy incorporates well-stablished landscape management practices.

In particular, forest management has been claimed for quite some time [15-17] to be a good solution to prevent a wide range of hydrogeological hazards [13] and is the base of the "protection forest" concept, documented in Europe since the 16th century [18]. More commonly, vegetation and particularly dense and well-managed forests have proved to be profitable tools to reduce soil erosion and landslide occurrence after heavy rains thanks to plant-induced soil water suction [19] and to the anchoring effect of roots [20]. In the same direction, scientists have been claiming for more than two decades that revegetating degraded bare lands has a great potential for soil stabilization and mitigation of risks derived from climate change [21,22]. Concerning snow avalanches, it is known that vegetation increases the roughness of the ground surface, which is a key to reduce snow gliding and to reinforce the anchorage of the snow cover to the slope surface [23,24].

Assessing the preoperative state of the environment and monitoring the effects on climate and biodiversity of the NBSs overtime is key for keeping restoration efficient since environmental impacts, very often, unfold over long periods [25]. However, this assessment is hindered by the lack of robust systems of environmental indicators suitable to be applied across a broad range of geographic and temporal scales. A variety of indicators are available to assess ecosystem response to restoration actions, most of them relying on plant community structure and composition [26,27], and recently some of them have been refined to monitor ecosystem resilience to climate change [28,29]. However, there is still an alarming lack of indicators informing about soil response to manipulation. Postrestoration 
trajectories of biodiversity and of ecosystem services are extremely variable in pattern (including stochastic responses) and in rate of change. In temperate regions, in particular, postimpact ecosystem evolution is slow, and the restored system might not attain the desired state within the timeframe of the restoration projects [30]. This is particularly true for effects on soil, since most indicators can take more than 50 years to recover [31].

In view of this scenario, to facilitate the evaluation of the success of NBSs in providing cobenefits, monitoring programs must be accurately designed before any action is carried out. Monitoring programs should include: (a) sectoral-specific sets of indicators that satisfy the basic criteria of meaningfulness, relevance, accuracy, understandability, standardization potential, cost-efficiency, and applicability [32,33], (b) a preoperative assessment of the base-line for each indicator, (c) a clear postoperational sampling and analytical program matching those applied for the base-line description, and (d) reference values for the each indicators over time.

Here we present a methodological framework designed to monitor the collateral benefits of NBSs designed for hydro-meteorological related risk reduction on important environmental services (climate change mitigation and biodiversity) provided by soil and vegetation. The framework includes soil (organic $C$ (carbon), $C$ sequestration, water erosion, structure, stability, water holding capacity, fertility, microbial and invertebrate functional diversity) and vegetation (aboveground tree carbon stock, species diversity, invasive species, total and non-woody species cover and plant moisture and flammability) indicators. To demonstrate the validity of the proposed methodology, the framework has been tested in two locations of the French and Spanish Pyrenees. Both the methodological framework and the locations are provided based on the PHUSICOS project (EU, H2020). We also discuss the pros and cons of each indicator and to what extent it meets the abovementioned requirements.

\section{The Work Cases}

\subsection{Snow Avalanches in the Capet Forest (Barèges, France)}

Barèges (Hautes-Pyrénées, 42.895994, 0.062309) is located at the base of the Capet mountain (2328 m.a.s.l.). With a stable population of 170 people, this is a popular holiday destination thanks to its proximity to sky resorts and thermal baths. The town is threatened by destructive snow avalanches that are well documented since 1644 [34]. The Capet Forest, a 147 ha public national forest above Barèges, was planned as an antiavalanche protective forest in 1860 which prompted the active reforestation of the area with coniferous trees [34]. To reinforce the protection provided by the forest, dry stone walls were built in 1892 and, from then on, the defence system has been significantly improved and densified. Currently, about 900 protective structures (5232 lineal meters) are maintained by the ONF/RTM (National Forest Office/Mountain Land Restoration) staff (Figure 1). Notwithstanding this deployment of protective measures, the avalanches continue to cause damages.

A new approach to risk reduction is now being tested which aims at preventing snow avalanches from the very beginning of their formation at the top of the avalanche corridors. The proposed solution consists of supporting reforestation with snow glide tripods of $2.5 \mathrm{~m}$-long sides (Figure 2) to favour tree establishment in drop shaped plantation areas of $4 \times 5 \mathrm{~m}$. This strategy is very common in the Alpine region and, in its original version, the tripods are placed in groups less than $1.5 \mathrm{~m}$ from each other to mimic the clumpy structure of the subalpine forests [35]. Under each tripod, seedlings are planted following the "nucleation" strategy. 


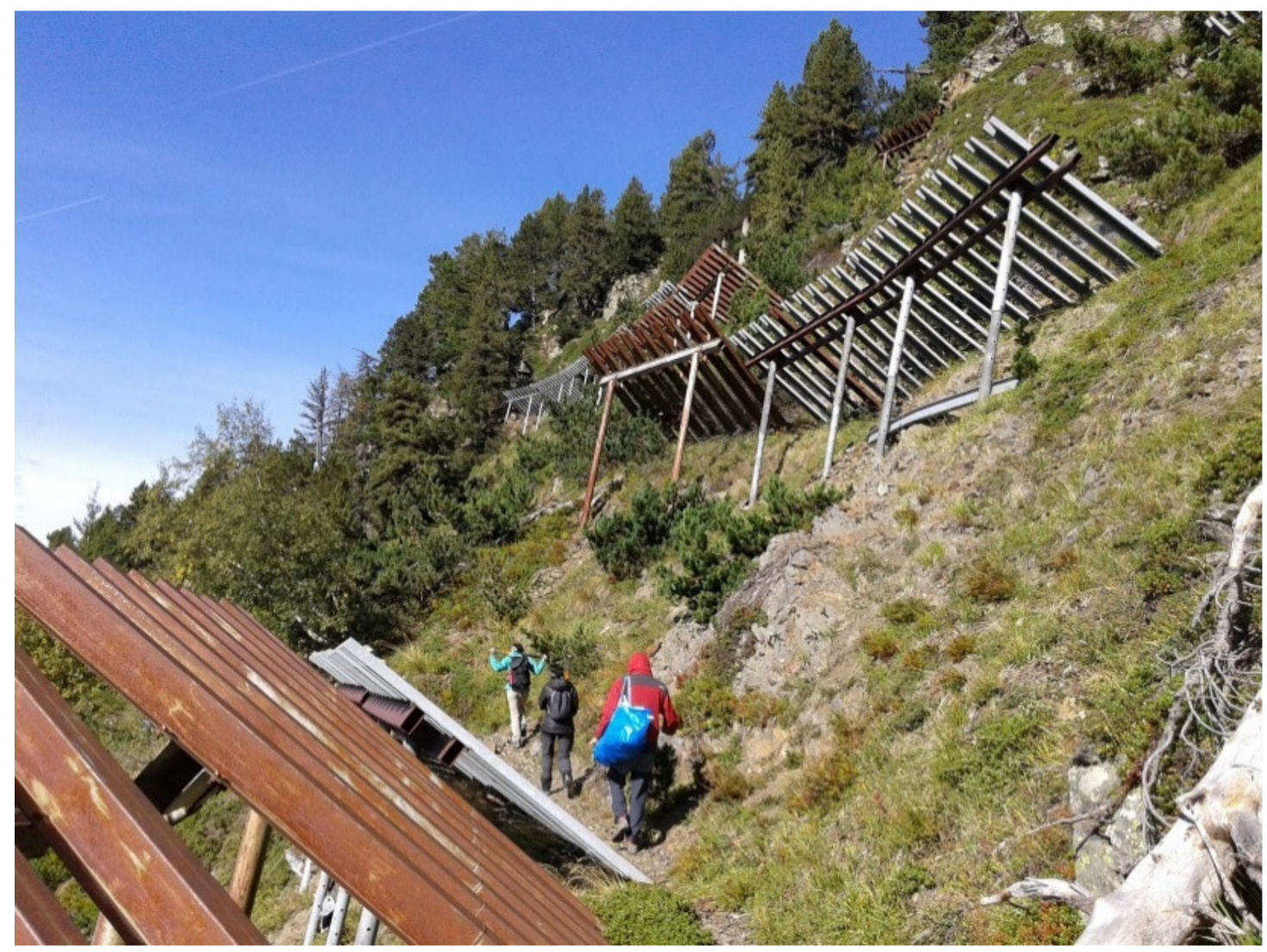

Figure 1. Anti-avalanche structures in Thiel corridor above Barèges.

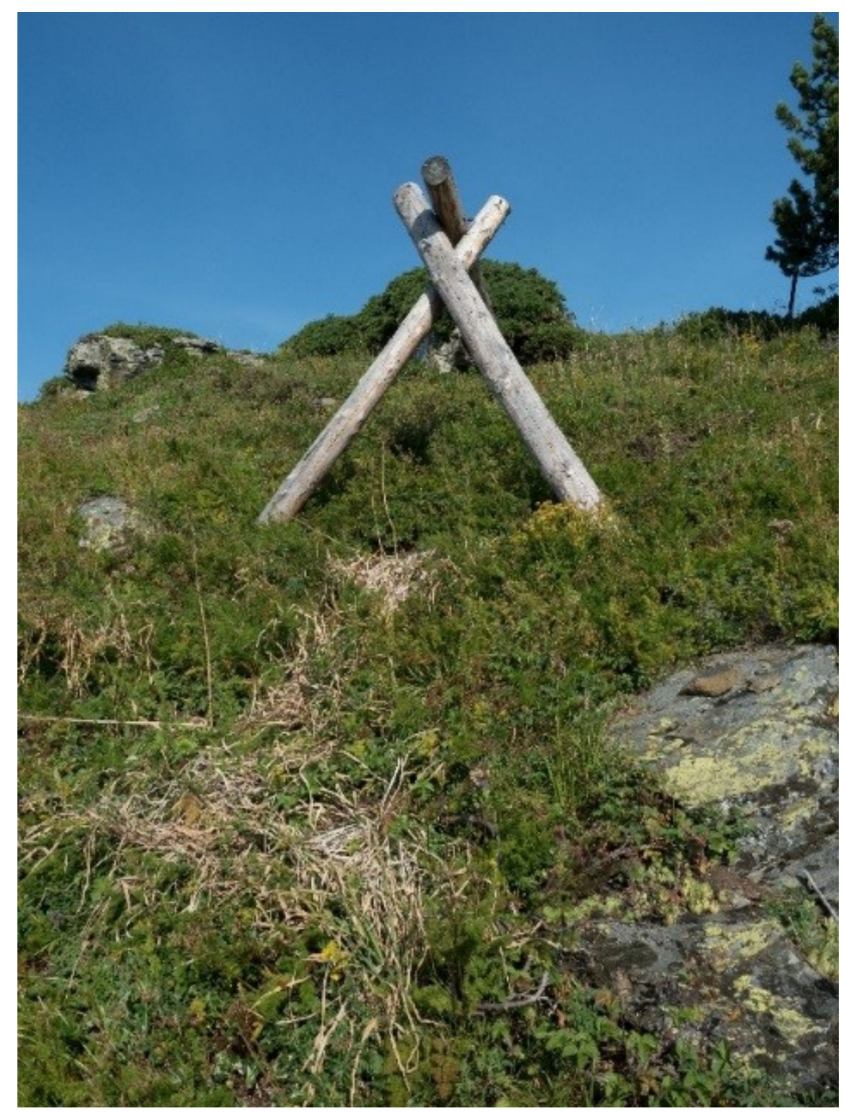

Figure 2. Seedling plantation in microterraces under woody tripods. 
The resulting small patches of trees will later act as focal areas for forest recovery across the slope. The ensuing vegetation pattern is expected to increase soil roughness which will impede snow gliding at its origin. This, in turn, will prevent the snowpack from gaining momentum [36]. In the Capet Forest, 30 to 50 tree seedlings of coniferous species (mainly Pinus uncinata) are currently being manually planted under each tripod in small microterraces to avoid soil disturbance.

\subsection{Rock Falls in the Santa Elena Road Cut (Biescas, Spain)}

The very busy A-136 transnational road from Biescas (Spain) to Laruns (France) is threatened by rock falls from a road cut excavated perpendicular to a Quaternary moraine $(42.659647,-0.324108)$. The cutting is triangular and $35 \mathrm{~m}$ high with a base $150 \mathrm{~m}$ long and $75^{\circ}$ slope (Figure 3).

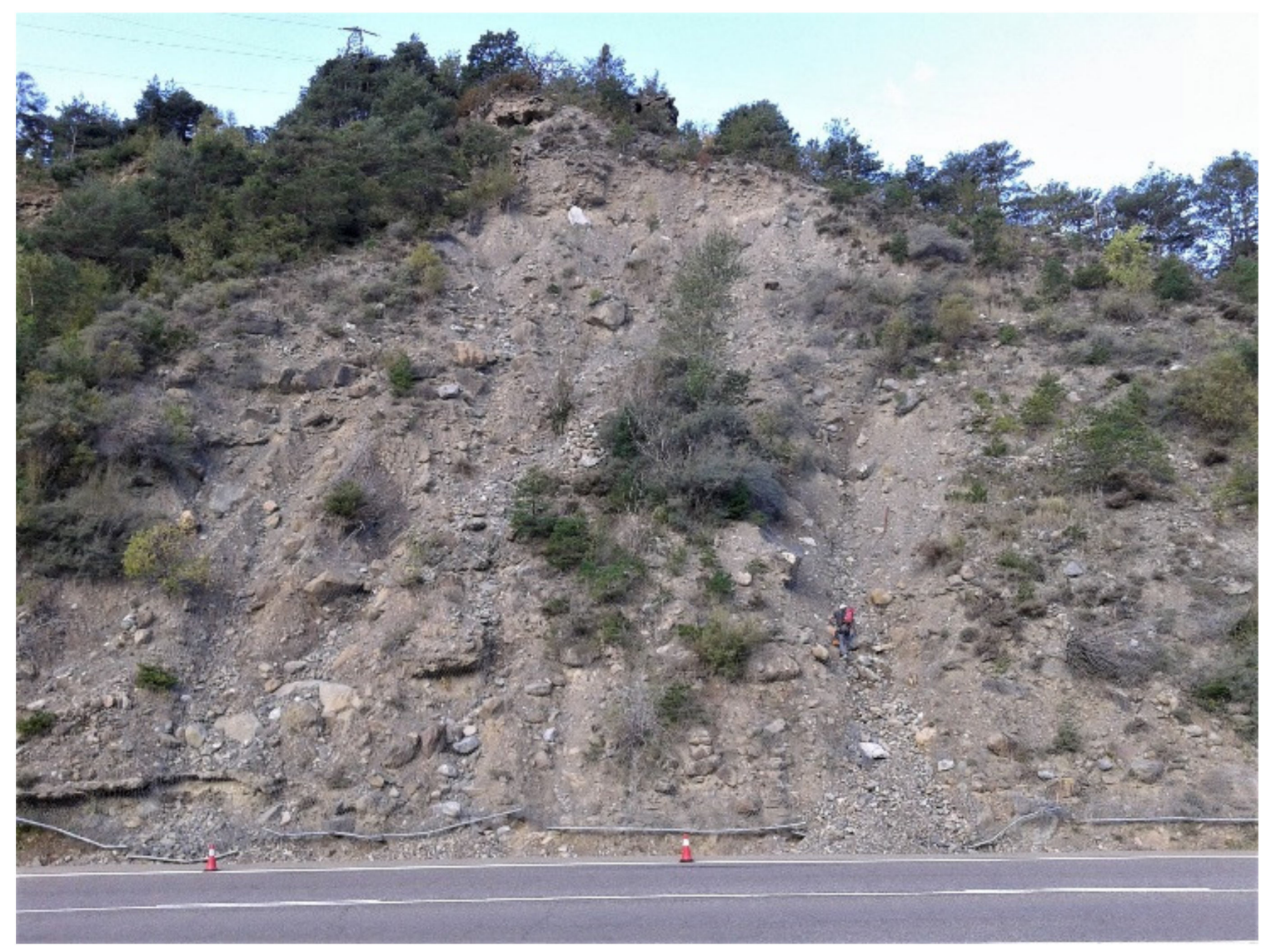

Figure 3. Sediment instability in the Santa Elena road cut.

To stabilize the cutting, the proposed NBS is a small-scale adaptation of the successful restoration of the, at the time, fully deforested Arratiecho watershed $(42.629104,-0.308481$, undertaken in 1903 [37]. The works included the stabilization of the hillsides by terracing, the drainage of the rainwater and the reforestation of the terraces mainly with Pinus sylvestris and Hippophae rhamnoides (Figure 4). Although the last details of the works included in the proposed NBS still are under debate, it is clear that, after cutting sanitation, the stable rocky outcrops will be spared to guarantee heterogeneity and, finally, terracing and water drainages will be implemented before revegetation. 


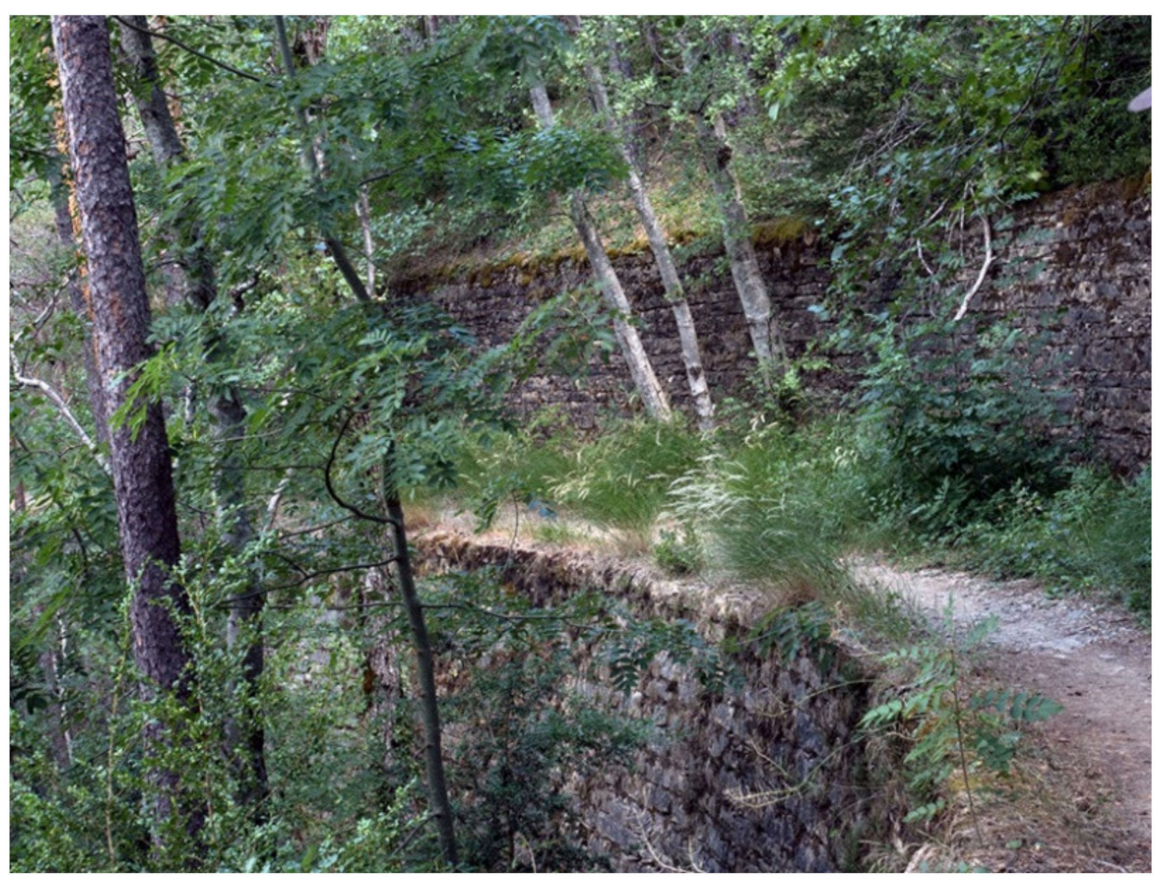

Figure 4. Stabilization terraces in the Arratiecho watershed.

\section{A Set of Indicators for NBS Effects on Soil and Vegetation}

The NBSs considered in our study cases have significant effects on the environmental services provided by soil and vegetation in terms of climate change mitigation and biodiversity conservation. To assess these effects, we selected the set of indicators shown in Table 1. Selection was performed under the activities of the PHUSICOS project (EU H2020). In 2018, a first tentative list of environmental indicators was proposed, based on consultation to experts. During 2019, this preliminary matrix was presented individually to the responsible of the demonstrator sites for selection of the indicators to be specifically applied at each site. Based on this selection, we worked in profiling the best methods to adjust these indicators to the specificities of each study case. Here, we describe the environmental interpretation of each of them.

\subsection{Soil Indicators}

For monitoring purposes, our soil indicators are designed for calculation in the upper 15 centimetres of the soil profile.

\subsubsection{Soil Organic Carbon (SOC) Content}

Organic carbon is the main component (about $58 \%$ ) of the soil organic matter (SOM) and is often used as a proxy for it. SOM is made of plant and animal substances in various stages of decomposition, as well as of microbial cells and products, and is vital for the delivery of soil ecosystem services. At the local scale, SOM plays a crucial role in soil fertility, soil resistance to erosion and soil water holding capacity. At the global scale, SOM dynamics is a key factor in the global carbon and nitrogen cycle and in ecosystem resilience [38]. SOC global stocks are estimated at an average of $1500 \mathrm{PgC}$ in the first meter of the soil profile [39], which is more than all carbon contained in the atmosphere and terrestrial vegetation combined [40]. For all these reasons, SOM and SOC are fundamental for soil quality evaluation, and are always included in postrestoration monitoring programs [41]. A comprehensive review of the current and emerging methods for soil $\mathrm{C}$ estimation can be found in Nayak et al. [42]. 


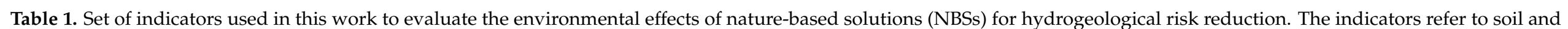

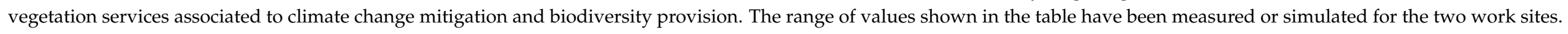

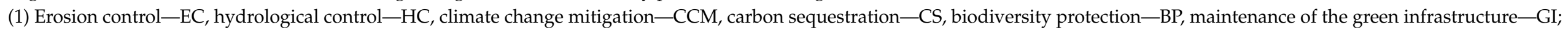

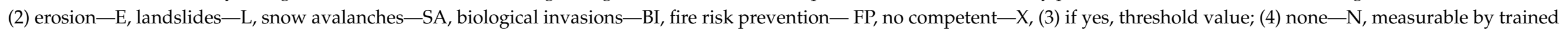

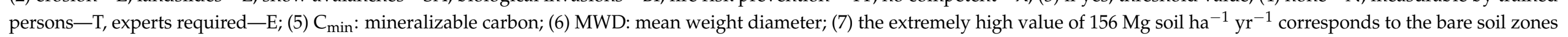
of the Santa Elena road cut. In the vegetated slopes of the Santa Elena and Capet Forest areas, the highest erosion tax is $4.6 \mathrm{Mg} \mathrm{soil} \mathrm{ha}^{-1} \mathrm{yr}^{-1}$.

\begin{tabular}{|c|c|c|c|c|c|c|c|c|c|}
\hline & $\begin{array}{c}\text { Environmental } \\
\text { Services }\end{array}$ & Indicators & $\begin{array}{l}\text { Range of } \\
\text { Values }\end{array}$ & Units & $\begin{array}{l}\text { Optimal Value } \\
\text { (if Pertinent) }\end{array}$ & $\begin{array}{c}\text { Related } \\
\text { Ecological } \\
\text { Functions (1) }\end{array}$ & $\begin{array}{l}\text { Competence for } \\
\text { Risk Reduction (2) }\end{array}$ & $\begin{array}{c}\text { Flag Value } \\
\text { Required? (3) }\end{array}$ & $\begin{array}{c}\text { Expertise } \\
\text { Required (4) }\end{array}$ \\
\hline \multirow{13}{*}{ नृ: } & \multirow{4}{*}{$\begin{array}{l}\text { Belowground C } \\
\text { sequestration }\end{array}$} & $\begin{array}{l}\text { Organic carbon in the topsoil } \\
\qquad(15 \text { top } \mathrm{cm})\end{array}$ & $50-400$ & $\mathrm{MgC} \mathrm{ha}^{-1}$ & $>20$ & $\mathrm{CCM}, \mathrm{CS}, \mathrm{BP}$ & $\mathrm{E}$ & $<5$ & $\mathrm{~T}$ \\
\hline & & \multirow{3}{*}{$\begin{array}{c}\text { Recalcitrant } C \\
\text { Labile } C \text { in microaggregates } \\
\mathrm{C} \text { mineralisation by the soil } \\
\text { food web }\end{array}$} & $23-95$ & $\%$ & $>20$ & CCM,CS,BP & $\mathrm{E}$ & $<5$ & $\mathrm{~T}$ \\
\hline & & & $0-88$ & $\% \operatorname{Cmin}(5)$ & $?$ & $\mathrm{CCM}, \mathrm{CS}, \mathrm{BP}$ & $\mathrm{E}$ & no & $\mathrm{T}$ \\
\hline & & & $20-1600$ & $\mathrm{kgC} \mathrm{ha}^{-1} \mathrm{yr}^{-1}$ & 1600 & $\mathrm{CCM}, \mathrm{CS}, \mathrm{BP}$ & $x$ & no & $\mathrm{E}$ \\
\hline & \multirow{3}{*}{$\begin{array}{l}\text { Soil physical } \\
\text { resilience }\end{array}$} & Water erosion & $0.04-156(7)$ & $\begin{array}{l}\text { Mg soil ha } \\
\text { yr }^{-1}\end{array}$ & & CCM, CS & $\mathrm{E}$ & $>1,45$ & $\mathrm{~T}$ \\
\hline & & Soi aggregate stability & $0.75-3.3$ & MWD (6) & $>2$ & $\mathrm{CCM}, \mathrm{CS}, \mathrm{BP}$ & E,L & $<0.4$ & $\mathrm{~T}$ \\
\hline & & Soil water holding capacity & $0.2-1.3$ & $\mathrm{~g} \mathrm{H}_{2} \mathrm{O} \mathrm{g}^{-1}$ soil & $>1$ & $\mathrm{BP}$ & E,L & $<0.5$ & $\mathrm{~T}$ \\
\hline & \multirow{2}{*}{ Soil fertility } & $\begin{array}{l}\text { Nutrients: total nitrogen } \\
\text { (Kjeldahl) }\end{array}$ & $15-120$ & $\mathrm{Mg} \mathrm{N} \mathrm{ha}^{-1}$ & variate & CS,BP & $x$ & variate & $\mathrm{T}$ \\
\hline & & Nutrients: P (Olsen) & $0.01-0.04$ & $\mathrm{Mg} \mathrm{P} \mathrm{ha}^{-1}$ & variate & CS,BP & $X$ & variate & $\mathrm{T}$ \\
\hline & \multirow{3}{*}{$\begin{array}{l}\text { Biodiversity } \\
\text { provison }\end{array}$} & $\begin{array}{l}\text { Microbial community } \\
\text { physiological profiling } \\
\text { (Eveness Index) }\end{array}$ & $0.92-0.98$ & Unitless & - & CS,BP & BI & no & $\mathrm{E}$ \\
\hline & & $\begin{array}{l}\text { Bacterial genetic diversity } \\
\text { (Eveness index) }\end{array}$ & $0.39-0.44$ & Unitless & - & CS,BP & BI & no & $\mathrm{E}$ \\
\hline & & $\begin{array}{l}\text { Bacterial genetic diversity } \\
\text { (Richness index) }\end{array}$ & 105-199 & Unitless & - & $\mathrm{CS}, \mathrm{BP}$ & BI & no & $\mathrm{E}$ \\
\hline & $\begin{array}{l}\text { Biological } \\
\text { resilience }\end{array}$ & Food web stability (s) & $0.001-0.02$ & $\mathrm{~s}$ & 0.001 & CCM, CS,BP & $x$ & no & $\mathrm{E}$ \\
\hline
\end{tabular}


Table 1. Cont.

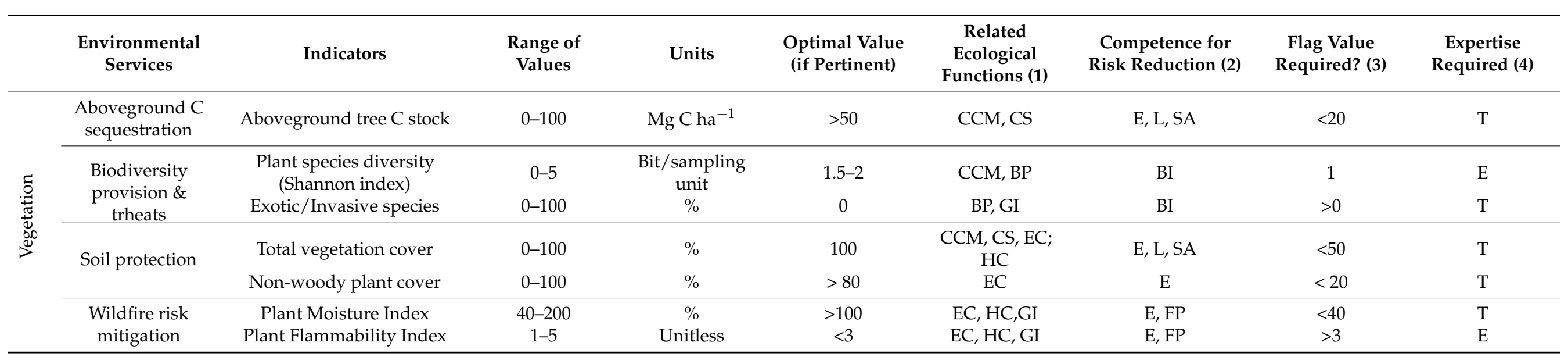


Under the geographical and climatic conditions of our study cases, SOC is expected to increase over time after the application of the NBSs. As ecosystem recovery progresses, SOC in the affected zones is expected to converge to those levels measured in the neighbouring mature land units. In the monitoring program, SOC should be measured every five years.

\subsubsection{Carbon Sequestration in Soil: Chemical and Physical Protection}

Soil organic matter mineralization (or "decomposition") is the consequence of microbial nutrition and metabolism. Heterotrophic microbes exploit SOM as a source of energy and, as a product of their respiration, the SOM-C is released into the atmosphere as $\mathrm{CO}_{2}$. At the same time, other nutrients retained in SOM are made available to plants [43].

SOM includes a variety of chemical forms of different decomposability. Depending on their attractiveness for soil microbial attack, three different SOM fractions may be identified: a small labile fraction, very actively utilized by the microorganisms with a turnover within two or three years; a slow fraction, with a turnover of 20-40 years; and a large passive fraction, very recalcitrant and with a turnover $>2500$ years. The labile fraction is extremely responsive to changes in climate, plant composition and soil manipulation, and alerts of incipient soil degradation/rehabilitation faster that chemical and physical soil indicators. The causes of SOM recalcitrance are complex, with both chemical and physical factors involved [44].

Largely, SOM recalcitrance depends on the chemical properties of the primary plant material, with polyaromatic structures among the most recalcitrant chemical species, and carbohydrates, proteins, or phospholipid fatty acid among the most labile [45]. Evidence is growing that SOM recalcitrance also depends on its physical preservation into the soil. SOM can remain stored for millennia into organo-mineral complexes (produced by the sorption between SOM and clay minerals and metallic colloids), and SOM occlusion within small-size soil aggregates significantly delays microbial attack [46].

Here we propose to use the percentage of carbon belonging to the recalcitrant fraction of the SOM in relation to total organic carbon as an indicator of SOC chemical recalcitrance.

After NBS application, as vegetation progresses over the restored area from herbaceous to wood-dominated communities, SOM recalcitrance is expected to increase [47].

We also propose the use of the fraction of labile $C$ contained in soil microaggregates (0.53-2 $\mu \mathrm{m}$ diameter) as an indicator of the physical protection that soil provides to organic carbon [48]. After soil restoration, we expect increasing $C$ incorporation into soil micro-aggregates.

A solid overview of the physical and chemical methods for soil fractionation can be obtained from von Lützow et al. [49], and methods to determine soil aggregate size distribution by wet sieving are available from Soinne et al. [50]. In the framework of a monitoring program, SOM recalcitrance and physical protection of the soil C should be measured every five years.

\subsubsection{Water Erosion}

Soil erosion can be defined as the accelerated removal of topsoil from the land surface through water, wind, or tillage [40], and deforestation, overgrazing and construction are among the most powerful erosive factors in mountains [51]. The mean soil loss rate in the European Union erosion-prone lands (agricultural, forests and seminatural lands) is about

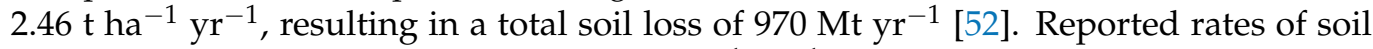
formation are within a range of 0.3 to $1.45 \mathrm{t} \mathrm{ha}^{-1} \mathrm{yr}^{-1}$ for European soils [53], which is the maximum tolerable erosion rate to maintain a stable soil pool.

Water erosion, the most extensive form of erosion occurring in Europe, depends on several factors, including topography, plant cover, land management, rainfall erosivity and soil erodibility. Soil erodibility, in turn, is determined by soil intrinsic properties such as texture and organic matter content. In our work, erosion is calculated using the universal soil-loss equation (USLE), which considers all the above-mentioned factors [54]. 
The different terms in the USLE equation are calculated or estimated for each slope using remote sensing and field data.

Immediately after NBS application, erosion may increase due to soil disturbance caused by the required field work and by the poor development of the protective plant cover. To correctly evaluate NBS effects, erosion values should be registered previous to NBS implementation, immediately after and then yearly for five years. A new evaluation 10 years after operation is advisable. In the case of the Capet Forest, where soil and plant cover disturbance are kept to a minimum during operation, erosion can be assessed every five years after NBS application.

\subsubsection{Soil Structure Stability: Aggregate Stability}

Soil aggregate stability is a key indicator of soil resistance to physical degradation. Soil structure partly depends on the presence of stable aggregates composed of primary particles and organic and inorganic binding agents. The stability of an aggregate refers to its ability to resist stresses such as tillage, swelling, shrinking processes and fast wetting by rain and, in general, to every mechanical or physical chemical disturb that causes aggregate disintegration. Structure is an important soil property that exerts direct influence over ecosystem services provided by soil, such as supporting plant growth and animal life, sequestering carbon and guaranteeing water quality [55].

The analytic methods followed in this work to measure aggregate stability can be retrieved from Le Bissonnais [56] and Shirazi and Boersma [57].

Land degradation usually results in decline of soil structure. In the study cases, the application of the proposed NBSs is expected to improve soil structure over time and, consequently, to increase aggregate stability. For a correct monitoring, this indicator should be checked every five years.

\subsubsection{Soil Water Holding Capacity}

Soil water holding capacity (WHC) is a simple measure of soil ability to provide water for plant growth. WHC is a hydraulic propriety of the soil and is the amount of water available to plants that soil can hold against the force of gravity. WHC is defined by the amount of water held by soil between field capacity and permanent wilting point. WHC assessment in laboratory is straightforward, and several methods can be found in Dane and Topp [58] or other manuals about soil analyses. WHC is governed by soil texture and SOM content. The first depends strongly on parent material, and SOM is expected to increase due to the application of NBSs that promote soil enrichment. As for other soil indicators informing about physical characteristics, we recommend measuring WHC every five years after restoration works are completed.

\subsubsection{Soil Fertility}

Available nutrients, well-adjusted texture, correct physical structure and low or no salinity are required conditions for soil fertility and plant growth to improve. In any terrestrial environment, nutrient limitation has the capacity to transform the structure and functioning of ecosystems [59]. Soil acidity is a paramount factor in determining nutrient availability. For example, calcium, potassium and magnesium are available in basic soils, while iron, manganese, zinc or copper are more available in acidic soils and phosphorous is available to plants at intermediate values of soil acidity [60]. It is very difficult to propose reference values for each of the indicators included under the "soil fertility" umbrella, because different plant covers have distinctive nutrient requirements, thrive under different soil acidity and tolerate different levels of saline stress. Preventive analytics can be recommended every five years.

\subsubsection{Soil Microbial and Invertebrate Functional Biodiversity}

Soil harbours a large part of the world's biodiversity. By far the most abundant group of soil organisms are microbes (e.g., viruses, bacteria, archaea and fungi) that, together 
with invertebrates (mainly protozoa, nematodes, mites, springtails, enchytraeids and earthworms), underlie crucial soil functions and provide environmental services such as carbon sequestration, water cycle regulation, nutrient cycling, decontamination and bioremediation, plant diversity regulation and plant and human health protection. Soil biodiversity evaluation is also important to estimate the resilience of terrestrial ecosystems [33,61].

A practical way to handle the enormous task of evaluating soil biodiversity is to substitute taxonomic diversity by functional diversity. We can do this by grouping the species into guilds of organisms that perform comparable functions and show similar metabolic and behavioural responses to environmental factors. In fact, it has been argued that it is functional rather than taxonomic biodiversity that is important for the long-term stability of an ecosystem [62]. Here, we propose assessing soil functional diversity through three complementary perspectives: (a) soil food webs, (b) soil bacterial functional gene diversity, and (c) soil microbial community level physiological profiling.

- Carbon mineralization by soil food webs, and soil community stability

Food webs depict trophic relationships between different groups of the soil biota (who eats whom and how much each one eats of the other) and, therefore, they characterize the forces predators exert on their prey and vice versa. A key advantage of this ordination of soil biodiversity is that, once the biomass of each trophic group (from field sampling and further classification of microbes and invertebrates) and their chemical and metabolic characteristics are known, the flux of energy and matter through the system can be calculated [63].

A very important output of soil food web models is carbon mineralization rate and consequent $\mathrm{CO}_{2}$ emissions to the atmosphere [64]. Another meaningful indicator that can be calculated from food web schemes is stability. Food web stability is a measure of the likelihood of the persistence of the soil species or functional groups following disturbances or environmental impacts. Stability guarantees enduring diversity and preserving the provision of soil environmental services in front of environmental fluctuations, which is primeval under current climate uncertainty [65]. Soil food web concepts and energetic food web models, addressed to calculate $\mathrm{CO}_{2}$ production and ecosystem stability (s), are exhaustively described in Moore and de Ruiter [66]. To facilitate the interpretation of data in Table 1, one must note that the lower $s$ gets, the higher the ecosystem stability becomes.

- Soil bacterial functional gene diversity

Microbial functional diversity can be defined as 'the sum of the ecological process, and/or the capacity to use different substrates developed by the microorganisms of a community' [67]. The diversity of functions performed by organisms within ecosystems has been recognized as the missing link between biodiversity patterns and ecosystem functions. Functional gene analysis is included in the list of powerful indicators aimed to monitor soil biodiversity and ecosystem function across Europe [68]. Shotgun Metagenome Sequencing can reveal taxonomic profiling (diversity and abundance), as well as functional attributes of soil microbial communities. The methodological approach followed in this work is reviewed in Quince et al. [69].

- $\quad$ Soil microbial community level physiological profiling

Community level physiological profiling (CLPP) is an estimation of soil microbial functional diversity and indicates the metabolic ability of soil microbial community. CLPP can be assessed by measuring microbial utilization of a wide range of carbon sources. MicroResp ${ }^{\mathrm{TM}}$ is an appropriate, rapid and sensitive method for determination of soil microbial CLPPs. The MicroResp ${ }^{\mathrm{TM}}$ assay is highly recommended to monitor functional soil biodiversity [68]. We posit that the ability of the soil microbial community to metabolize increasingly recalcitrant chemicals will rise both with time and with ecosystem maturation after the application of the proposed NBSs.

Belowground communities fluctuate seasonally, with the highest abundance and activity occurring during the plant growing period. Therefore, sampling campaigns for soil biodiversity should be conducted in April-September in the two study cases of the 
Pyrenees, preferably in the same period of the year chosen to assess their pre-operational value. For monitoring programs, soil biodiversity should be monitored every five years, together with SOM status.

\subsection{Vegetation Indicators}

\subsubsection{Aboveground Tree Carbon Stock}

The aboveground tree carbon stock is the amount of $\mathrm{C}$ stored in the aboveground of living trees expressed in tons of $C$ per hectare. The stock of $C$ in forest trees is the result of the balance between its increase as a result of tree growth and its decrease by tree exploitation and mortality [70]. If tree growth surpasses the losses, the result is C accumulation; on the contrary, if losses exceed growth, the stock of $C$ decreases. The aboveground $C$ stock should be monitored every five years during the 10 years following the restoration.

\subsubsection{Plant Species Diversity: Shannon Index}

The Shannon Index $\left(\mathrm{H}^{\prime}\right)$ is a measure of diversity and is a function of the number of species and their proportion [71]. This indicator is dimensionless. As a measure of species diversity, $\mathrm{H}^{\prime}$ is calculated as $\mathrm{H}^{\prime}=\Sigma \mathrm{p}_{\mathrm{i}} \cdot \ln \left(\mathrm{p}_{\mathrm{i}}\right)$ where, for each species observed in a plot, $\mathrm{p}_{\mathrm{i}}$ is the relative number of individuals or the proportion of total the plot cover contributed by the $\mathrm{i}^{\text {th }}$ plant species. For the two study sites in this work, $\mathrm{p}_{\mathrm{i}}$ is based on the total plant cover of each species. A five-year periodicity is advisable for postrestoration plant diversity monitoring.

\subsubsection{Exotic/Invasive Species}

The proportion of exotic invasive species is an indicator of the degree of ecosystem disturbance. A species is considered invasive when it rapidly colonizes and occupies a space by altering its ecological integrity and ecosystem services [72,73] by hindering the regeneration, establishment and growth of native species. Moreover, the presence of invasive species disrupts the fundamental structure and function of the ecosystem food webs, and consequently reduces native biodiversity [74]. Annual monitoring of the restored areas and surroundings is recommended during the first five years to prevent the establishment of potential invaders.

\subsubsection{Total Vegetation Cover}

This indicator measures the proportion of soil covered by vegetation (trees, shrubs, herbaceous vegetation, bryophytes and lichens). A larger vegetation cover means a lower proportion of bare soil and, consequently, a lower risk of erosion. If vegetation is absent, soil is more exposed to erosive agents. The total vegetation cover should be calculated every five years following the restoration works.

\subsubsection{Non-Woody Plant Cover}

As "total vegetation cover", but considering only herbaceous vegetation (grasses), ferns, bryophytes and lichens. Following the considerations of the previous indicator in relation to erodibility, it is important to take into account not only the total vegetation cover but also the structure of the understory vegetation (height and percent cover) to quantify the erosive effect of the raindrop impact on the soil. Greater coverage and low height of understory vegetation means higher protection of soil against erosion. Plant cover is crucial to control erosion and should be monitored every five years.

\subsubsection{Plant Moisture Index}

This index indicates the moisture content of fine fuel (i.e., live and dead fuel, less than $6 \mathrm{~mm}$ in size and with high surface-area-to-volume ratio, that dries promptly and is rapidly consumed by fire when dry) of all woody species. Moisture content of fine fuels is known to be an important factor in flammability and fire behaviour [75]. The plant 
moisture index (PMI) varies throughout the year depending on climate conditions, and it also varies between species. Some species are able to maintain a high and relatively constant moisture content while others have a lower moisture capacity. The PMI or water content (in \%) is determined as:

$$
P M I=\frac{\text { fresh weight }- \text { dry weight }}{d r y \text { weight }} \cdot 100
$$

This indicator should be monitored every fifteen days during at least the driest period of the year selecting various samples of the most abundant woody species.

\subsubsection{Plant Flammability Index}

Flammability is the ability of a fuel to ignite after being exposed to caloric energy [76,77]. The fuel flammability classification is based on the classic definitions of Anderson [78] and Martin [79]. Flammability of forest fuels mainly depends on the structure, surface-volume ratio, bulk density, and fuel packing [80]. At each site, the flammability index must be calculated in the driest period of the year and reflects the relative importance of each plant species previously classified by its specific flammability value according to five categories: 1 . very low flammability; 2 . low flammability; 3 . moderate flammability; 4. high flammability and 5 . very high flammability. This indicator should be monitored every fifteen days during at least the driest period of the year selecting various samples of the most abundant woody species.

\section{Evaluation of Indicators after Application on the Study Sites}

All proposed soil indicators allow to evaluate the main environment cobenefits as all vegetation indicators (Table 1 ). Related to meaningfulness, almost all the indicators of soil physical resilience, belowground $C$ sequestration and biodiversity provision allow to assess the risk reduction of the NBSs proposed in both work cases. They are also important because they make it possible to evaluate the health of the soil and its capacity to carry out its ecological functions. In the case of the indicators of soil biodiversity it is not possible to define an optimal value [81]. Furthermore, this kind of indicator needs an expertise and are expensive.

Particularly to water erosion, the range of values for both the Santa Elena and the Capet Forest study cases goes from relatively low $\left(0.04 \mathrm{tha}^{-1} \mathrm{yr}^{-1}\right)$ to exceedingly high $\left(156 \mathrm{tha}^{-1} \mathrm{yr}^{-1}\right)$ values. Some of these computed values are higher than the flag value of $1.45 \mathrm{tha}^{-1} \mathrm{yr}^{-1}$. The highest values correspond to the extremely erodible substrate of the Santa Elena road cut, but specific calibration for some parameters may be required for our models to yield accurately predictions [82], especially for catchments with very high slopes $(>45 \%)$ like those in Santa Elena and the Capet forest study cases.

Most of the proposed vegetation indicators allow to evaluate the main environmental cobenefits of the NBSs (Table 1). Related to meaningfulness, aboveground tree C stock and total vegetation cover allow to assess the risk reduction provided by the NBSs proposed in both work cases. They are also relevant because all vegetation indicators make it possible to evaluate at least one of the proposed ecological functions, and understandable and useful, because it has been possible to associate an optimal value and a flag value to each of them with reference to their associated ecological functions. The days spent on field sampling and subsequent data treatment showed that the proposed monitoring system is easily applicable, cost-efficient, although two out of seven proposed indicators need expertise and training.

\section{Discussion}

The proposed indicators are presented including potential range values and expected evolution. Such information is rarely offered; in fact, there are few studies about NBS indicators and their use. In general, the study of nature-based solutions has increased progressively since the beginning of the 2010s until 2020, from a few articles published in 
the first half of the decade to almost 200 in 2020 alone (for the years 1998-2020, based on ISI Web of Science search using the topic words "nature based solution*"). However, the proportion of such NBS studies including indicators remains very low, around $7 \%$ (search terms "nature based solution*" AND "indicator" on ISI Web of Science). If we consider the soil dimension, the proportion of NBS studies that examine soils is also small, almost $15 \%$ (search terms "nature based solution*" AND "soil"), and a similar proportion is obtained when only the studies mentioning indicators are included ("nature based solution" AND "indicator*" AND "soil"). In any case, when analysed in detail, one sees that all these studies are focused on urban environments, except one article [83] on catchment scale NBSs to reduce erosion. Although NBSs have been applied and studied using a wide range of different terms (e.g., green-blue infrastructure, ecological engineering, etc., whose analysis exceed the scope of this paper [84]), using NBSs as the single term in the bibliography search provides an interesting picture on the subject.

Indicators should indeed be easy to use, but there is a balance between accuracy and usefulness. To be pertinent, indicators should be devised to address a clear objective (or target), and their design should make them useful and understandable in a management context $[33,85]$. If the objective of the NBSs is to maintain or restore soil health, several issues have been outlined. Indicators of soil health should relate easily and straightforwardly to soil biology, should be applicable under conditions other than those of traditional agricultural systems and should provide rapid, management-relevant soil testing [81]. In this sense, we believe that the microbial indicators included in our studies cover a sufficiently wide range of considerations and are both efficient and useful. Moreover, and unlike well-known indicators of soil quality as the GISQ [86] or QBS-ar [87], the use of microbe-related indicators increases the value of the proposed methodology.

Unfortunately, working with soil food webs requires expertise for identification and computation of the different groups, as well as further modelling. Therefore, monitoring their postoperation evolution is very desirable but not feasible unless the monitoring plan includes funds for contracting expert assistance. There is an urgent need to find reliable relationships between soil food web complex indexes and other biological indexes of soil quality that are easier to calculate.

In fact, indicators are requested to be (1) meaningful, i.e., related to important ecological functions to ensure accuracy, (2) standardized, to ensure the comparability of data among sites, and (3) measurable and cost-efficient, or easy to sample, affordable, and not restricted to high expertise [33]. We have already discussed the meaningfulness of the proposed indicators and have provided the necessary information to, at least, initiate the necessary standardization. Although it could be argued that some of them do not fulfil all conditions outlined in (3), we believe that a balance between accuracy and easiness to use is imperative. When considering other relevant criteria such as policy relevance (for example, by allowing comparisons between a baseline situation and an achievable target), spatial-temporal coverage (e.g., considering different soil types and land uses) and understandability and accuracy (reflecting precisely the potential changes under monitoring) [33], the proposed indicators meet expectations very well.

In relation to the reliability of the proposed indicators at landscape scales, several considerations are properly accomplished. For example, in order to include reliable and robust measures that cover multiple types of land cover and management, as well as causes and effects, landscape indicators ought to be more consistent and based on systematic measurements over time of spatially explicit land qualities (among others, carbon and nutrient stocks, soil quality, net primary productivity, and biodiversity) [88].

Robust and common indicators, with well-defined monitoring schemes within and across habitats, are urgently needed to monitor the loss of biodiversity and the implications for the sustainable provision of ecosystem services [89]. We think that the proposed indicators, although in the need of more studies to be standardized and the requirement of a certain level of expertise, are a keystone in the establishment and monitoring of NBS in forested environments, especially those in risk of landslide and snow avalanche 
Author Contributions: Draft preparation, P.A., E.D.-M. and S.M.; soil sampling and lab assessment of soil indicators, P.A., E.D.-M. and S.M.; vegetation inventories and assessment of plant indicators, J.V., M.G. and J.P.; erosion and food web modelling, R.M.-H.; digital cartography, J.G. All authors have read and agreed to the published version of the manuscript.

Funding: This research was funded by the European Community's Seventh Framework Programme through the grant to the PHUSICOS Project (https: / / phusicos.eu/) (EU H2020 Research and Innovation Programme grant agreement No. 776681).

Institutional Review Board Statement: Not applicable.

Informed Consent Statement: Not applicable.

Data Availability Statement: Not applicable.

Acknowledgments: We would like to thank Santiago Fábregas, Director of the "Espacio Portalet" (Biescas), Edith Michel-Villaz, from the Service RTM Hautes-Pyrénées et Pyrénées-Atlantiques and the mountain crew of the ONF/RTM for their warm hospitality and enthusiastic cooperation that made it possible our field campaigns.

Conflicts of Interest: The authors declare no conflict of interest.

\section{References}

1. IPCC. Managing the Risks of Extreme Events and Disasters to Advance Climate Change Adaptation; A Special Report of Working Groups I and II of the Intergovernmental Panel on Climate Change; Field, C.B., Barros, V., Stocker, T.F., Qin, D., Dokken, D.J., Ebi, K.L., Mastrandrea, M.D., Mach, K.J., Plattner, G.-K., Allen, S.K., et al., Eds.; Cambridge University Press: Cambridge, UK; New York, NY, USA, 2012.

2. Field, C.B.; Barros, V.R.; Mach, K.J.; Mastrandrea, M.D.; van Aalst, M.; Adger, W.N.; Arent, D.J.; Barnett, J.; Betts, R.; Bilir, T.E.; et al. Technical summary. In Climate Change 2014: Impacts, Adaptation, and Vulnerability. Part A: Global and Sectoral Aspects; Field, C.B., Barros, V.R., Dokken, D.J., Mach, K.J., Mastrandrea, M.D., Bilir, T.E., Chatterjee, M., Ebi, K.L., Estrada, Y.O., Genova, R.C., et al., Eds.; Cambridge University Press: Cambridge, UK; New York, NY, USA, 2014; pp. 35-94.

3. European Commission. The Implementation of the Soil Thematic Strategy and Ongoing Activities; Report from the Commission to the European Parliament, the Council, the European Economic and Social Committee and the Committee of the Regions, COM(2012) 46 final; European Commission: Brussels, Belgium, 2012.

4. Wilde, M.; Günther, A.; Reichenbach, P.; Malet, J.-P.; Hervás, J. Pan-European landslide susceptibility mapping ELSUS version 2. J. Maps 2018, 14, 97-104. [CrossRef]

5. Mateos, R.M.; López-Vinielles, J.; Poyiadji, E.; Tsagkas, D.; Sheehy, M.; Hadjicharalambous, K.; Liscáke, P.; Podolskif, L.; Laskowiczg, I.; Iadanzah, C.; et al. Integration of landslide hazard into urban planning across Europe. Landsc. Urban Plan. 2020, 196, 103740. [CrossRef]

6. Beniston, M.; Farinotti, D.; Stoffel, M.; Andreassen, L.M.; Coppola, E.; Eckert, N.; Fantini, A.; Giacona, F.; Hauck, C.; Huss, M.; et al. The European mountain cryosphere: A review of its current state, trends, and future challenges. Cryosphere 2018, 12, 759-794. [CrossRef]

7. Hock, R.; Rasul, G.; Adler, C.; Cáceres, B.; Gruber, S.; Hirabayashi, Y.; Jackson, M.; Kääb, A.; Kang, S.; Kutuzov, S.; et al. High mountain areas. In IPCC Special Report on the Ocean and Cryosphere in a Changing Climate; Pörtner, H.-O., Roberts, D.C., Masson-Delmotte, V., Zhai, P., Tignor, M., Poloczanska, E., Mintenbeck, K., AlegríA, A., Nicolai, M., Okem, A., et al., Eds.; 2019; In press.

8. Cornforth, D.H.; Cornforth, D. Landslides in Practice: Investigation, Analysis, and Remedial/Preventative Options in Soils. John Wiley \& Sons Inc: Hoboken, NJ, USA, 2005.

9. Bowman, E.T. Small landslides-Frequent, costly, and manageable. In Landslide Hazards, Risks and Disasters; Daviess, T., Shroder, J.F., Eds.; Elsevier: Amsterdam, The Netherlands, 2015; pp. 405-439.

10. Canadian Avalanche Association. Technical Aspects of Snow Avalanche Risk Management-Resources and Guidelines for Avalanche Practitioners in Canada; Canadian Avalanche Association: Revelstoke, BC, Canada, 2016.

11. International Union for Conservation of Nature. 2012 IUCN Annual Report Nature+ Towards Nature-Based Solutions; IUCN: Gland, Switzerland, 2013.

12. Faivre, N.; Fritz, M.; Freitas, T.; de Boissezon, B.; Vandewoestijne, S. Nature-based solutions in the EU: Innovating with nature to address social, economic and environmental challenges. Environ. Res. 2017, 159, 509-518. [CrossRef]

13. Arce-Mojica, T.; Nehren, U.; Sudmeier-Rieux, K.; Miranda, P.J.; Anhuf, D. Nature-based solutions (NbS) for reducing the risk of shallow landslides: Where do we stand? Int. J. Disaster Risk Reduct. 2019, 41, 101293. [CrossRef]

14. European Commission. Policy Topics: Nature-Based Solutions. Available online: https://ec.europa.eu/info/research-andinnovation/research-area/environment/nature-based-solutions_en. (accessed on 1 January 2021).

15. Teich, M.; Bartelt, P.; Grêt-Regamey, A.; Bebi, P. Snow avalanches in forested terrain: Influence of forest parameters, topography, and avalanche characteristics on runout distance. Arct. Antarct. Alp. Res. 2012, 44, 509-519. [CrossRef] 
16. Sakals, M.E.; Innes, J.L.; Wilford, D.J.; Sidle, R.C.; Grant, G.E. The role of forests in reducing hydrogeomorphic hazards. For. Snow Landsc. Res. 2006, 80, 11-22.

17. Brang, P.; Schönenberger, W.; Frehner, M.; Schwitter, R.; Wasser, B. Management of protection forests in the European Alps: An overview. For. Snow Landsc. Res. 2006.

18. Wiśniewski, P.; Märker, M. The role of soil-protecting forests in reducing soil erosion in young glacial landscapes of NorthernCentral Poland. Geoderma 2019, 337, 1227-1235. [CrossRef]

19. Yildiz, A.; Graf, F.; Springman, S.M. An investigation of plant-induced suction and its implications for slope stability. Geotech. Eng. 2019, 172, 520-529. [CrossRef]

20. Rickli, C.; Bebi, P.; Graf, F.; Moos, C. Shallow landslides: Retrospective analysis of the protective effects of forest and conclusions for prediction. In Recent Advances in Geotechnical Research; Wu, W., Ed.; Springer International Publisher: Cham, Switzerland, 2019; pp. 175-185.

21. Lal, R. Soil management and restoration for C sequestration to mitigate the accelerated greenhouse effect. Prog. Environ. Sci. 1999, 1,307-326.

22. Paustian, K.; Lehmann, J.; Ogle, S.; Reay, D.; Robertson, G.P.; Smith, P. Climate-smart soils. Nature 2016, 532, 49-57. [CrossRef]

23. Ancey, C. Snow avalanches. In Geomorphological Fluid Mechanics; Springer: Berlin/Heidelberg, Germany, 2001 ; pp. 319-338.

24. Höller, P. Snow gliding and glide avalanches: A review. Nat. Hazards 2014, 71, 1259-1288. [CrossRef]

25. Raymond, C.M.; Berry, P.; Breil, M.; Nita, M.R.; Kabisch, N.; de Bel, M.; Enzi, V.; Frantzeskaki, N.; Geneletti, D.; Cardinaletti, M.; et al. An Impact Evaluation Framework to Support. Planning and Evaluation of Nature-Based Solutions Projects; Centre for Ecology \& Hydrology: Wallingford, UK, 2017.

26. McElhinny, C.; Gibbons, P.; Brack, C.; Bauhus, J. Forest and woodland stand structural complexity: Its definition and measurement. For. Ecol. Manag. 2005, 218, 1-24. [CrossRef]

27. Wortley, L.; Hero, J.M.; Howes, M. Evaluating ecological restoration success: A review of the literature. Restor. Ecol. 2013, 21, 537-543. [CrossRef]

28. Jaunatre, R.; Buisson, E.; Muller, I.; Morlon, H.; Mesléard, F.; Dutoit, T. New synthetic indicators to assess community resilience and restoration success. Ecol. Indic. 2013, 29, 468-477. [CrossRef]

29. Timpane-Padgham, B.L.; Beechie, T.; Klinger, T. A systematic review of ecological attributes that confer resilience to climate change in environmental restoration. PLoS ONE 2017, 12, e0173812. [CrossRef] [PubMed]

30. Bullock, J.M.; Aronson, J.; Newton, A.C.; Pywell, R.F.; Rey-Benayas, J.M. Restoration of ecosystem services and biodiversity: Conflicts and opportunities. Trends Ecol. Evol. 2011, 26, 541-549. [CrossRef]

31. Insam, H.; Domsch, K.H. Relationship between soil organic carbon and microbial biomass on chronosequences of reclamation sites. Microb. Ecol. 1988, 15, 177-188. [CrossRef]

32. Ritz, K.; Black, H.I.J.; Campbell, C.D.; Harris, J.A.; Wood, C. Selecting biological indicators for monitoring soils: A framework for balancing scientific and technical opinion to assist policy development. Ecol. Indic. 2009, 9, 1212-1221. [CrossRef]

33. Turbé, A.; De Toni, A.; Benito, P.; Lavelle, P.; Lavelle, P.; Ruiz, N.; Van der Putten, W.; Labouze, E.; Mudgal, S. Soil Biodiversity: Functions, Threaths and Tools for Policy Makers; Report for European Commission (DG Environment); Bio Intelligence Service: Paris, France; IRD: Paris, France; NIOO: Paris, France, 2010.

34. Lanusse, M. Risques et aménagements à Barèges. Revue Géographique des Pyrénées et du Sud-Ouest. Sud-Ouest Européen 1988, $59,58-71$.

35. Technical Avalanche Protection Handbook; Rudolf-Miklau, F.; Sauermoser, S.; Mears, A. (Eds.) Wilhelm Ernst \& Sohn: Berlin, Germany, 2014.

36. Corbin, J.D.; Holl, K.D. Applied nucleation as a forest restoration strategy. For. Ecol. Manag. 2012, 265, 37-46. [CrossRef]

37. Fábregas, S.M.; Mintegui, J.A.; Hurtado, R.; Robredo, J.C.; Huelin, P. Evaluación de la protección conseguida en la cuenca de un torrente de montaña ante los daños causados por eventos torrenciales mediante su restauración hidrológico-forestal. Cuenca del torrente de Arratiecho en el Pirineo Aragonés, España. In Proceedings of the 8a Assembleia Luso Espanhola de Geodesia e Geofísica, Évora, Portugal, 29-31 January 2014.

38. FAO. Soil Organic Carbon: The Hidden Potential; Food and Agriculture Organization of the United Nations: Rome, Italy, 2017.

39. Scharlemann, J.P.; Tanner, E.V.; Hiederer, R.; Kapos, V. Global soil carbon: Understanding and managing the largest terrestrial carbon pool. Carbon Manag. 2014, 5, 81-91. [CrossRef]

40. Food and Agriculture Organization of the United Nations. Status of the World's Soil Resources; FAO: Rome, Italy, 2015.

41. Mukhopadhyay, S.C. Wearable sensors for human activity monitoring: A review. IEEE Sens. J. 2014, 15, 1321-1330. [CrossRef]

42. Nayak, A.K.; Rahman, M.M.; Naidu, R.; Dhal, B.; Swain, C.K.; Nayak, A.D.; Tripathi, R.; Shahid, M.; Islam, M.R.; Pathak, H. Current and emerging methodologies for estimating carbon sequestration in agricultural soils: A review. Sci. Total Environ. 2019, 665, 890-912. [CrossRef]

43. Van Elsas, J.D.; Trevors, J.T.; Rosado, A.S.; Nannipieri, P. Modern Soil Microbiology; CRC Press: Boca Raton, FL, USA, 2019.

44. Kleber, M. What is recalcitrant soil organic matter? Environ. Chem. 2010, 7, 320-332. [CrossRef]

45. Engel, M.; Macko, S. Organic Geochemistry: Principles and Applications; Plenum Press: New York, NY, USA, 1993.

46. Dungait, J.A.; Hopkins, D.W.; Gregory, A.S.; Whitmore, A.P. Soil organic matter turnover is governed by accessibility not recalcitrance. Glob. Chang. Biol. 2012, 18, 1781-1796. [CrossRef] 
47. Pregitzer, K.S.; Euskirchen, E.S. Carbon cycling and storage in world forests: Biome patterns related to forestage. Glob. Chang. Biol. 2004, 10, 2052-2077. [CrossRef]

48. Six, J.; Elliott, E.T.; Paustian, K. Soil macroaggregate turnover and microaggregate formation: A mechanism for C sequestration under no tillage agriculture. Soil Biol. Biochem. 2000, 32, 2099-2103. [CrossRef]

49. Von Lützow, M.; Kögel-Knabner, I.; Ekschmitt, K.; Flessa, H.; Guggenberger, G.; Matzner, E.; Marschner, B. SOM fractionation methods: Relevance to functional pools and to stabilization mechanisms. Soil Biol. Biochem. 2007, 39, 2183-2207. [CrossRef]

50. Soinne, H.; Hovi, J.; Tammeorg, P.; Turtola, E. Effect of biochar on phosphorus sorption and clay soil aggregate stability. Geoderma 2014, 219, 162-167. [CrossRef]

51. Grimm, M.; Jones, R.; Montanarella, L. Soil Erosion Risk in Europe; European Soil Bureau Institute for Environment \& Sustainability, JRC: Ispra, Italy, 2001.

52. Panagos, P.; Borelli, P. Soil erosion in Europe: Current status, challenges and future developments. In All That Soil Erosion: The Global Task to Conserve Our Soil Resources; Soil Environment Center of the Korea. 2017. Available online: https:/ / ec.europa.eu/ $\mathrm{jrc} / \mathrm{en} /$ publication/soil-erosion-europe-current-status-challenges-and-future-developments (accessed on 1 January 2021).

53. Verheijen, F.G.; Jones, R.J.; Rickson, R.J.; Smith, C.J. Tolerable versus actual soil erosion rates in Europe. Earth-Sci. Rev. 2009, 94, 23-38. [CrossRef]

54. Wischmeier, W.H. Use and misuse of the Universal Soil Loss Equation. J. Soil Water Conserv. 1976, 31, 5-9.

55. Bronick, C.J.; Lal, R. Soil structure and management: A review. Geoderma 2005, 124, 3-22. [CrossRef]

56. Le Bissonnais, Y.L. Aggregate stability and assessment of soil crustability and erodibility: I. Theory and methodology. Eur. J. Soil Sci. 1996, 47, 425-437. [CrossRef]

57. Shirazi, M.A.; Boersma, L. A unifying quantitative analysis of soil texture. Soil Sci. Soc. Am. J. 1984, 48, 142-147. [CrossRef]

58. Dane, J.H.; Topp, C.G. Methods of Soil Analysis, Part. 4: Physical Methods; SSSA Book Series no 5; Soil Science Society of America: Madison, WI, USA, 2002.

59. Vitousek, P.M.; Porder, S.; Houlton, B.Z.; Chadwick, O.A. Terrestrial phosphorus limitation: Mechanisms, implications, and nitrogen-phosphorus interactions. Ecol. Appl. 2010, 20, 5-15. [CrossRef] [PubMed]

60. Sparks, D.L. Environmental Soil Chemistry; Elsevier: San Diego, CA, USA, 2003.

61. Bardgett, R.D.; van der Putten, W.H. Belowground biodiversity and ecosystem functioning. Nature 2014, 515, 505-511. [CrossRef]

62. Walker, B.; Kinzig, A.; Langridge, J. Plant attribute diversity, resilience, and ecosystem function: The nature and significance of dominant and minor species. Ecosystems 1999, 2, 95-113. [CrossRef]

63. Moore, J.C.; Walter, D.E.; Hunt, H.W. Arthropod regulation of micro- and mesobiota in below-ground detrital food webs. Annu. Rev. Entomol. 1988, 33, 419-435. [CrossRef]

64. De Ruiter, P.C.; Van Veen, J.A.; Moore, J.C.; Brussaard, L.; Hunt, H.W. Calculation of nitrogen mineralization in soil food webs. Plant Soil 1993, 157, 263-273. [CrossRef]

65. Schwarz, B.; Barnes, A.D.; Thakur, M.P.; Brose, U.; Ciobanu, M.; Reich, P.B.; Rich, R.L.; Rosenbaum, B.; Stefanski, A.; Eisenhauer, N. Warming alters energetic structure and function but not resilience of soil food webs. Nat. Clim. Chang. 2017, 7, 895. [CrossRef] [PubMed]

66. Moore, J.C.; de Ruiter, P. Energetic Food Webs: An Analysis of Real and Model Ecosystems; Oxford University Press: Oxford, UK, 2012.

67. Nannipieri, P.; Ascher, J.; Ceccherini, M.T.; Landi, L.; Pietramellara, G.; Renella, G. Microbial diversity and soil functions. Eur. J. Soil Sci. 2003, 68, 12-26. [CrossRef]

68. Griffiths, S.M.; Fox, G.; Briggs, P.J.; Donaldson, I.J.; Hood, S.; Richardson, P.; Leaver, G.W.; Truelove, N.K.; Preziosi, R.F. A Galaxy-based bioinformatics pipeline for optimised, streamlined microsatellite development from Illumina next-generation sequencing data. Conserv. Genet. Resour. 2016, 8, 481-486. [CrossRef] [PubMed]

69. Quince, C.; Walker, A.W.; Simpson, J.T.; Loman, N.J.; Segata, N. Shotgun metagenomics, from sampling to analysis. Nat. Biotechnol. 2017, 35, 833-844. [CrossRef]

70. Vayreda, J.; Martínez-Vilalta, J.; Gracia, M.; Retana, J. Recent climate changes interact with stand structure and management to determine changes in tree carbon stocks in Spanish forests. Glob. Chang. Biol. 2012, 18, 1028-1041. [CrossRef]

71. Shannon, C.E. The mathematical theory of communication. In The Mathematical Theory of Communication; Shannon, C.E., Weaver, W., Eds.; University of Illinois Press: Urbana, IL, USA, 1949.

72. Charles, H.; Dukes, J.S. Impacts of invasive species on ecosystem services. In Biological Invasions; Nentwig, W., Ed.; Springer: Berlin, Germany, 2008; pp. 217-238.

73. Pejchar, L.; Mooney, H.A. Invasive species, ecosystem services and human well-being. Trends Ecol. Evol. 2009, 24, 497-504. [CrossRef]

74. Ehrenfeld, J.G. Ecosystem consequences of biological invasions. Annu. Rev. Ecol. Evol. Syst. 2010, 41, 59-80. [CrossRef]

75. Dias, S.; Castro Rego, F.; Catry, F.; Guerrero, C.; Portela, C. Fuel moisture content in Mediterranean woody species throughout the year. In Proceedings of the VI International Conference on Forest Fire Research, Coimbra, Portugal, 15-18 November 2010.

76. Elvira, L.M.; Hernando, C. Inflamabilidad y Energía de las Especies de Sotobosque: Estudio Piloto con Aplicación a los Incendios Forestales; Colección Monografías; INIA: Madrid, Spain, 1989.

77. Valette, J.C. Inflammabilité d'espèces forestières méditerranéennes: Conséquences sur la combustibilité des formations forestières. Rev. For. Fr. 1990, 42, 76-92.

78. Anderson, H.E. Forest fuel ignitability. Fire Tech. 1970, 6, 312-319. [CrossRef] 
79. Martin, R.E.; Gordon, D.A.; Gutierrez, M.E.; Lee, D.S.; Molina, D.M.; Schroeder, R.A.; Sapsis, D.B.; Stephen, S.L.; Chambers, M. Assessing the flammability of domestic and wildland vegetation. In Proceedings of the 12th Conference on Fire and Forest Meteorology, 26-28 October 1993, Jekyll Island, GA, USA; Society of American Foresters Publication: Washington, DC, USA, $1994 ;$ pp. $130-137$.

80. Madrigal, J.; Hernando, C.; Guijarro, M.; Díez, C.; Marino, E.; De Castro, A.J. Evaluation of forest fuel flammability and combustion properties with an adapted mass loss calorimeter device. J. Fire Sci. 2009, 27, 323-342. [CrossRef]

81. Fierer, N.; Wood, S.A.; Bueno de Mesquita, C.P. How microbes can, and cannot, be used to assess soil health. Soil Biol. Biochem. 2021, 153, 108-111. [CrossRef]

82. Alewell, C.; Borrelli, P.; Meusburger, K.; Panagos, P. Using the USLE: Chances, challenges and limitations of soil erosion modelling Int. Soil Water Conserv. Res. 2019, 7, 203-225. [CrossRef]

83. Turconi, L.; Faccini, F.; Marchese, A.; Paliaga, G.; Casazza, M.; Vojinovic, Z.; Luino, F. Implementation of nature-based solutions for hydro-meteorological risk reduction in small Mediterranean catchments: The case of Portofino Natural Regional Park, Italy. Sustainability 2020, 12, 1240. [CrossRef]

84. Nature Editorials. Natural language: The latest attempt to brand green practices is better than it sounds. Nature 2017, 541, 133-134.

85. Failing, L.; Gregory, R. Ten common mistakes in designing biodiversity indicators for forest policy. J. Environ. Manage. 2003, 68, 121-132. [CrossRef]

86. Velásquez, E.; Lavelle, P.; Andrade, M. GISQ, a multifunctional indicator of soil quality. Soil Biol. Biochem. 2007, 39, 3066-3080. [CrossRef]

87. Menta, C.; Conti, F.D.; Pinto, S.; Bodini, A. Soil Biological Quality index (QBS-ar): 15 years of application at global scale. Ecol. Indic. 2018, 85, 773-780. [CrossRef]

88. Dale, V.H.; Kline, K.L. Issues in using landscape indicators to assess land changes. Ecol. Indic. 2013, 28, 91-99. [CrossRef]

89. Feld, C.K.; Martins da Silva, P.; Sousa, J.P.; de Bello, F.; Bugter, R.; Grandin, U.; Hering, D.; Lavorel, S.; Mountford, O.; Pardo, I.; et al. Indicators of biodiversity and ecosystem services: A synthesis across ecosystems and spatial scales. Oikos 2009, 118, 1862-1871. [CrossRef] 